\title{
Towards a theology of the body. A spirituality of imperfection
}

\begin{abstract}
Human weakness, a disabled body, and fragile faith make a theology of vulnerability and finitude relevant. I was basically moulded in a theology which does not adequately address concrete daily life of vulnerable people who have disabilities. Traditionally theology does not deal with physical imperfection, decay and dying. Philosophies that separate the mind and body have a strong influence in Christian traditions. Dualism is antithetical to the reality of Christ who had a body himself. Henri Nouwen's spiritual journey of vulnerability and brokenness make his "Spirituality of imperfection" grounded in experience. To come to accepting disease and death as part of life gives meaning to "we have this treasure in jars of clay", according to 2 Cor 4:7.
\end{abstract}

\section{THE FAITH HEALER}

A few years ago I attended a Christian camp. At one of the sessions the main speaker called those forward who wanted to be healed. A friend of mine tried persuading me to go, but I refused. My friend really wanted to see me healed from Parkinson's disease and told the faith healer about my condition. I then did stand up and allowed him to pray for me. He laid his hands on me and prayed for total recovery - of Alzheimer's. I whispered that it was Parkinson's. No wonder no miracle happened, he prayed for the wrong condition.

I realised more than ever before that disease or disability is not necessarily something that could and perhaps should be cured by faith healing or medical treatment. Suffering is not always to be explained or to be understood; one just needs to accept it as part and parcel of life. The way persons with disabilities are treated sometimes though, make them feel they are objects and this should not be the case. They need affection from dear ones. They need solidarity from their friends and from people around them, acceptance. From God they need compassion.

We do not want sympathy, but empathy, understanding, and respect. Sometimes this happens in peculiar ways. For example, the other day I went to an end-of-season sale at Woollies and tried on some clothes. I came out of the fitting room still struggling to close my zip. The assistant asked me innocently if she could help me. Her concern left me with a smile!

This reminds me of the movie "Patch Adams" which is based on a true story. The medical care model at the Gesundheit Institute has it that patients are treated as friends. The health of the staff is as important as the health of patients. And care is infused with fun and play. (Wikipedia.)

I was basically moulded in a theology which is not adequately connected to the concrete daily lives of vulnerable people who have a "dis-ease", and therefore a theology that does not deal with disability, decay and dying. With the current article I would like to take the reader on a spiritual journey towards an "embodied Spirituality" (Van den Berg 2008). As we go along, we shall take a glimpse at different perspectives on a "Theology of the body / Theology of weakness", how it builds upon Incarnation and how it works towards a Spirituality of imperfection. Theology and spirituality are not separated. According to Thomas Aquinas and Karl Rahner, faith is to be lived in the first place (Egan 2005:14). 
To be disabled one way or another brings to mind the New Testament writer Paul, who states that we are like fragile clay jars (2 Cor 4:7); we have perishable bodies. Paul's image of treasure in clay jars reveals his

weakness, lack of eloquence, ordinariness, fragility, suffering, and hardships. ... While Paul's application of the image may have seemed outlandish, the image itself would have been familiar to Paul's audience. Cheap, fragile, often unattractive, and readily discarded, clay jars were part of everyday life - much like the plastic container of today. (Ashley 2008.)

With this metaphor the apostle does not make any distinction between body and soul. Paul is referring to the person as a whole. He continues in the next chapter: "our bodies are like a tent" ( 2 Cor 5:1) - our bodies are vulnerable, exposed to the powers of nature, wind and weather; bodies that could be contaminated with viruses and venom. It is interesting to note that the literal translation of John 1:14 - "the Word had become flesh and came to live amongst us" reads: "Jesus came and pitched his tent amongst us". This reminds us of Jesus' own vulnerability.

Luke's story of the birth of Jesus emphasises his frailty. In Chapter 2 Luke writes about the shepherds and the angels. An angel appeared among the shepherds announcing the Saviour's birth. The angel said they would find a sign: a baby wrapped in cloths and lying in a manger. Luke uses the word "sign" to underline the symbolism of helplessness. According to Wilson (2004:36), "this sign offers us a new perspective. God is a baby weak and defenceless". The baby in the manger pictures God in a baby body, little and innocent - "a symbol of God's weakness" (Coffin 2003:17). The historian Plinius explains the custom of swaddling: "'After that first experience of daylight, children have all their limbs swaddled, a severer bondage than that of any domestic animal'" (Müller 1995:2). God entered the world as "a helpless and fragile new born baby" (Forbes 2007:156), and in bondage, so to speak. There is no distance left between "the human and the divine" (Nouwen 2007).

The writer of Deutero-Isaiah uses the metaphor of a bruised reed which God will not break, to indicate God's compassion for frail and weak people and the special task God has in mind for them (Isaiah 42:3). "The Servant's gentleness, both as unassertiveness (v. 2) and as tenderness to the weak and inadequate (v. 3), is unmarred by any weakness of his own: the words fail and discouraged (v. 4) pointedly take up the Hebrew terms already used for dimly burning and bruised" (Kidner 1970:613).

As an old man, Qoheleth wrote a beautiful poem on ageing. The youth should remember their Creator,

before the sun and the light and the moon and the stars grow dark, and the clouds return after the rain; when the keepers of the house tremble, and the strong men stoop, when the grinders cease because they are few, and those looking through the windows grow dim; when the doors to the street are closed and the sound of grinding fades; when men rise up at the sound of birds, but all their songs grow faint; when men are afraid of heights and of dangers in the streets; when the almond tree blossoms and the grasshopper drags himself along and desire no longer is stirred... (Eccl 12:2-5b).

Sawyer (1975:519) comments, "'the famous allegory of growing old' remains at the centre of most modern interpretations of Eccl 12:1-6 and a grotesque list of geriatric symptoms that have been identified in the passage can readily be compiled; e.g., deafness, constipation, ischuria, 
acrophobia, and agoraphobia in vs. 4 anorexia, impotence, and white hair in vs. 5".

\section{SPIRIT OR BODY?}

The bias against the body as impure, sinful and distracting from the spiritual, is upsetting, and to attach primary importance to rational thinking, disturbing. Berry (1982:953) reckons: "It is not accidental that the mainstream of Western theological tradition seems to have had so little to say about the empirical human situation. The structure of Christian belief received its normative character in centuries dominated by the two intellectual movements that were radically dualistic and distrusted the materiality of humankind". He refers to the philosophies of Neo-Platonism and Gnosticism.

Neo-Platonism is defined as "a type of idealistic monism in which the ultimate reality of the universe is held to be an infinite, unknowable, perfect One" (The Neoplatonic Doctrine). Nous or "pure intelligence" comes from the One and its image is the world soul. From the world soul human beings have received their "lesser souls". According to this philosophy, "The most perfect being was the least physical, and had the least to do with the physical; that the way of salvation necessarily leads from the body, from the earthly-historical, to a realm of pure spirit" (Berry 1982:953). According to Plotinus (204-270 C.E.) who is considered the first main proponent of Neo-Platonism,

The bodily Kind, in that it partakes of Matter is an evil thing. What form is in bodies is an untrue-form: they are without life: by their own natural disorderly movement they make away with each other; they are hindrances to the soul in its proper Act; in their ceaseless flux they are always slipping away from Being. Soul, on the contrary, since not every Soul is evil, is not an evil Kind. - Enneads, 1.8.4. (Enneads 2011.)

Gnosticism also rejects the body and regards it as a prison for the soul. It opposes Incarnation. "Christ could not possibly have a body: (1) because the absolute cannot enter into a real union with the finite; and (2) because matter is evil, and the spiritual world is ever in conflict with it" (Heick 1965:72).

Sölle and Gloyes (1984:29) consider the dichotomy of body and spirit as "an idealistic spirituality", which is "the enemy of creational spirituality". However, remnants of the philosophies of dualism are still alive and kicking today. In the church, people's bodily needs, their physical abilities or disabilities are devalued when body and soul are separated (Harren 2009:274). Furthermore, the emphasis on a "theology of the infinite" has a strong influence on Christian traditions. This theology refers to "an inquiry into the identity and existence of divine beings, divine activity in history and nature, the purpose and destiny of human life as these are revealed by a being called 'God' to others called 'persons'" (Berry 1982:953). This dualistic world view is universal. In fact," $(w)$ hen religions arose, this disassociation became even more pronounced as the 'you are not your body' belief. Countless people in East and West throughout the ages have tried to find God, salvation, or enlightenment through the denial of the body" (Tolle 2005:95).

\section{ALL IN ONE BODY}

Dualism is antithetical to the reality of Christ who had a body himself. The traditional Christian view of the body is "something to be overcome in order to receive the joys of heaven. This is paradoxical since probably the most important article of Christian faith is that God became (hu) 
man" (insertion in brackets mine) (Isherwood \& Stuart 1998:15) - in Jesus.

The birth, death, resurrection and ascension of Jesus, all facets of the Gospel, and historical events of Jesus' ministry, took place in this one body. Jesus as swaddled infant and nailed grownup makes one recognize God's humanity and humility. "Incarnation and Eucharist need to be firmly tied into the concrete events and images of the baby in the manger and the body on the cross" (Naylor 1996). Jesus' physical resurrection and ascension emphasise God's bodyliness even more. "In some mysterious way the resurrection also has a physical dimension with those wonderful post-resurrection encounters: Mary wanting to hold Jesus, Thomas needing to see and touch Jesus' wounds to enable his acclamation 'My Lord and My God', and the breaking of bread bringing recognition of Jesus" (Naylor 1996).

The sacramental value of his body is associated with a sensory experience of the Gospel. "In the sacrament, Christ touches us in and through his own body that is broken for us. In so doing, Christ binds us to himself and to one another" (Harren 2009:274). Christians may just as well speak of the body as sacrament: "The sharing of Jesus in our humanity and our receiving and sharing the broken bread, bring us into bodily relationship and unity: we are one body in Christ" (Naylor 1996).

God is even perceived as disabled and powerless. "In the resurrected Jesus Christ, they saw not the suffering servant for whom the last and most important word was tragedy and sin, but the disabled God who embodied both impaired hands and feet and pierced side and the imago Dei" (Eiesland 1994:99). As mentioned before, God as baby became the "all-powerless God", completely dependent on human care (Nouwen 2007). "How can we be afraid of a God who wants to be 'God-with-us' and needs us to become 'Us-with-God'?", reflects Nouwen (2007).

Wentzel van Huyssteen reasons that when one fully understands the meaning of Jesus' bodiliness, compassion for fellow human beings becomes a divine action.

(T)he image of God is not found in some intellectual or spiritual capacity, but in the whole embodied human being, "body and soul". In fact, the image of God is not found in humans, but is the human, and for this reason imago Dei can be read only as imitation Dei; to be created in God's image means we should act like God, and so attain holiness by caring for others and for the world. (Van Huyssteen 2006:320.)

\section{SPIRITUALITY OF IMPERFECTION}

People's faith could be as vulnerable as their bodies are. Proverbially, for people with Parkinson's, their faith could be just as shaky as the tremor of their hands. Julian Müller (2011) and Anton van Niekerk (2005) address this theme. As Müller (2011) states, faith is vulnerable and unstable, wavering between conviction and terror, completely honest and tentative. Van Niekerk (2005:27) contends that living one's faith by loving one another and making the world a better place is more important than confessing a dogma and knowing exactly what one believes.

A fragile faith, human weakness and a disabled body, make a theology of vulnerability and finitude relevant. In his article, "Seeking a Theology of the Finite", Donald Berry refers to "A body theology". This kind of theology "must, in short, include, in a non-masochistic way, a theology of pain and suffering, a recognition that time and the healing powers of nature are not always efficacious; indeed, that in the final analysis, they are never more than temporarily successful" (Berry 1982:955).

Henri Nouwen's theology of weakness and powerlessness fits my understanding of a theology of the body best. Nouwen's personal spiritual journey of vulnerability and brokenness, and his pastoral ministry to persons with mental disability with their limitations and frailty, ground his 
"Spirituality of Imperfection" (Hernandez 2006) in authentic and unique experience. Nouwen (1998:19) acknowledges the spiritual importance of the human body:

In Jesus, God took on human flesh. The Spirit of God overshadowed Mary, and in her all enmity between spirit and body was overcome. Thus God's Spirit was united with the human spirit, and the human body became the temple destined to be lifted up into the intimacy of God through the Resurrection. Every human body has been given a new hope, of belonging eternally to the God who created it. Thanks to the Incarnation, you can bring your body home.

\section{AM MY BODY}

My body is mine; your body is yours - do not resist it. "Do not fight against the body, for in doing so you are fighting against your own body. You are your body." (Tolle 2005:96). The established author Nancy Mairs (1989:271), who has Multiple Sclerosis, writes: "I am somebody. A body. A difficult body to be sure, almost too weak now to stand, increasingly deformed, wracked still by gut spasm and headaches and menstrual miseries. But some body. Mine. Me. In establishing myself as writer, however modest my success, I have ceased to be nobody. I have written my way into embodied self, and here I am at home".

Humanity and Christianity are interrelated. Sölle and Gloyes (1984:29) explain:

My body tells me that I am in pain, hungry, have sexual needs. It is through my body that I know it is not so very good here on earth. The wrong way to relieve this tension is to deny and to suppress the body and its needs in favour of affirming an idealistic spirituality cleansed of all bodily desires.

Self discovery and discovering God go together. But this self who is being discovered, is a body (Naylor 1996). A way to come to know God is to listen to one's body (Harren 2004:279). Personal empowerment happens when one accepts one's body - "Transformation is through the body, not away from it" (Tolle 2005:95). One can be at home in one's body, because God is Emmanuel. God is not revealed to us "'up there', remote, but the God who is Emmanuel, the God who is with us, battered and bruised as we are, sharing our life in all its richness and also in all its sadness's and also our death" (Forbes 2007:156).

Louw (2005:16) calls our being "an embodied soul and a spirited body". We become a "Spirited body" when our physical bodies, infused with cultural heritage, have received "the Breath of God's Spirit" (Murphy 2006:ix). Then our being gives form and expression to "a new spirituality" (Nouwen 1998:32). My body is my embodied spiritual self!

It is the body that makes spiritual experience passionate, that brings to it intense desire and pleasure, pain, delight, and remorse. Without all these things, spirituality is bland. In the world's spiritual traditions, sex and art and music and dance and the taste of food have been for millennia forms of spiritual experience just as much as ritual practice, meditation, and prayer. (Lakoff \& Johnson 1999:568.)

\section{THE PARADOX OF LIFE}

Perspectives on a theology of the body are filled with paradoxes. We need God's compassion; God's power of suffering, serving, and acting. It is God's redeeming and restorative love that 
gives the Christian faith a solid base and credibility. However, God became part of humanity, allowing humanity to become part of God (2 Pet. 1:4). And now God's desire to be loved by us, can be fulfilled (Nouwen 2007). "People are not God's puppets, but persons with integrity and potential, whom God has engaged as his partners in each of the placid or painful phases of existence" (Ellens 1987:27).

Our bodiliness is paradoxical as well. Our strengths and weaknesses, pleasure but also discomfort and pain, are all reminders of our embodied existence which make a theology of the body relevant (Berry 1982:955). Health and disease are embraced as ways of living. Everybody gets ill; although some conditions are more serious than others (Ellens 1987:27). Subsequently, illness is not regarded as "an enemy, but a creation of the organism" (Ellens 1987:12). And we all die.

Body theology recognises the potential of humans, but within boundaries. "(T)he root of the human malaise is our giving in to the idolatrous desire to become just such a 'No-Limit Person'. ... Faith comes as the gift of accepting ourselves as 'a person with limits' - not grudgingly, not spitefully, but gratefully" (Berry 1982:955).

At the time of writing this article, a well-known rugby player made the headlines of an Afrikaans newspaper Die Burger. Joost van der Westhuizen, a former captain of the Springboks, has been diagnosed with a fatal neurological disease. We all are vulnerable, because we are human. Sometimes even babies are born with some disability. "Illness is an element on the growth continuum of conception-birth-life-death-and eternal life. It is a distortion of the comfortable and direct line of growth we idealize, from birth to self-actualization; but it is not the opposite of growth. Indeed, it is often a growth inducer" (Ellens 1987:15).

Moore (2004) reflects in Dark Nights of the Soul that during life's darkest hours the challenge is to restore oneself and to become someone with human dignity, depth and soul. My spiritual journey has brought about a faith that is "embodied in concrete living" (Ahner 2007:19). Spirited bodies embody imperfection. Each of us is like an African pot standing with its three legs of faith, hope and love in the ashes of last night's fire, still with the leftover in it to be enjoyed by our friends.

\section{BIBLIOGRAPHY}

Ahner, G. 2007. Business Ethics. Making a life, not just living. New York: Orbis Books.

Ashley, E. 2008. The scandal of weak leadership: Paul's defence of ministry. Online at http://www. lutterworth.com/pub/on\%20eagles\%20wings\%20ch5.pdf Accessed: 9 May 2011Berry, D. 1982.

Seeking a Theology of the Finite. Christian Century, 99, September: 953-956.

Coffin, W.S. 2003. God and the world's disorders. In Langford, J.R. \& Rouner, L.S (Eds.) Walking with God in a fragile world. Oxford: Rowman \& Litttlefield: 13-21.

Egan, H.D. 2005. Theology and Spirituality. In Marmion, D. \& Hines, M.E. (Eds.) The Cambridge Companions to Karl Rahner. Cambridge: Cambridge University Press: 13-28.

'Ek kan nie sê hoeveel tyd hy oor het nie' - Dokter. Joost ernstig siek. 2011. Die Burger, 13 Mei:1.

Eiesland, N.L. 1994. The Disabled God: Toward a Libratory Theology of Disability. Nashville: Abingdon Press.

Ellens, J.H. 1987. Psychotheology: Key issues. Pretoria: UNISA.

Enneads. Online at http://www.john-uebersax.com/plato/enneads.htm\#egf4. Accessed: 9 May 2011.

Forbes, G. 2007. And Finally ... Risk Assessment on Christmas Eve. The Expository Times, 119 (3):156.

Harren, J. 2009. Bones and Bread: Knowing God in our Bodies through the Communion Table. Journal of Religion, Disability \& Health, 13(3-4):274-292.

Heick, O.W. 1965. A History of Christian Thought. Philadelphia: Fortress.

Hernandez, W. 2006. Henri Nouwen: A Spirituality of Imperfection. Mahwah: Paulist Press.

Isherwood, L. \& Stuart, E. 1998. Introducing Body Theology. Sheffield: Sheffield Academic Press.

Kidner, D. 1970. Isaiah. In Guthrie, D. \& Motyer, J. (Eds.) The New Bible Commentary Revised. Leicester: 
Inter-Varsity Press: 588-625.

Lakoff, G. \& Johnson, M. 1999. Philosophy in the flesh. The embodied mind and its challenge to Western thought. New York: Basic Books.

Louw, D.A. 2005. Ratwerke van die menslike siel. Oor volwassenheid en lewensvaardighede. Stellenbosch: SUN Press.

Mairs, N. 1989. Remembering the Bone House. New York: Harper \& Row.

Moore, T. 2004. Dark nights of the soul. London: PIATKOS.

Müller, J. 1995. Die Barmhartigheid van Kersfees - Lukas 2:1-10. In Sinodale Kommissie vir die Diens van Barmhartigheid NGK Suid-Transvaal. Nood voor die deure van die kerk. NGK Suid-Transvaal: 1-6.

Müller, J. 2011. Om te mag twyfel. 'n Gelowige se reis. Cape Town: Tafelberg.

Murphy, N. 2002. Introduction. In Russel, R.J., Meyering, T.C. \& Arbib, M.A. (Eds.) Neuroscience and the person. Scientific perspectives on divine action. Berkeley: Center for Theology and the Natural Sciences: i-xxxv.

Naylor, V. 1996. The Theology of Touch. Online at

http://www. franciscanarchive.org.uk/1996jan-naylor. Accessed: 22 February 2011.

Nouwen, H. 2007. God's powerlessness. Online at

http://helenl.wordpress.com/2007/03/0/gods-powerlessness-by-henri-nouwen/Accessed: 2 May 2011.

Nouwen, H.J.M.. 1998. The inner voice of love. A Journey Through Anguish To Freedom. New York: Doubleday.

Sawyer, J.F.A. 1975. The ruined House in Ecclessiastes 12: A reconstruction of the original parable. Journal of Biblical Literature, 94(4), December: 519-531.

Sölle, D. \& Cloyes, S.A. 1984. To work and To love: A Theology of Creation. Philadelphia: Fortress Press.

The Holy Bible New International Version. 1983. Cape Town: Bible Society of South Africa.

The Neoplatonic Doctrine. Online at http://www.123HelpMe.com/view.asp?id=78872 Accessed: 5 May 2011.

Tolle, E. 2005. The Power of Now. A Guide to Spiritual Enlightenment. London: Hodder \& Stoughton.

Van den Berg, J.A. 2008. An embodied spirituality: Perspectives for a bodily pastoral anthropology. Acta Theologica, 2:118-132.

Van Huyssteen, J.W. 2006. Alone in the world? Human uniqueness in science and theology. The Gifford lectures. Grand Rapids: Eerdmans Publishing Company.

Van Niekerk, A. 2005. Geloof sonder sekerhede. Wellington: Bybel-Media.

Wikipedia. Patch Adams. Online at http://en.wikipedia.org/wiki/Patch_Adams. Accessed: 5 May 2011.

Wilson, W.J.G. 2004. A faith unfaithful (wrestling with belief). Indiana: Author House Bloomington.

\section{KEY WORDS}

Spirituality of imperfection

Dualism

Disability

Incarnation

spiritual journey

Body theology

\section{TREFWOORDE}

Onvolmaakte spiritualiteit

Dualism

Gestremdheid

Vleeswording

Spirituele reis

Lyfteologie

\author{
CONTACT DETAILS \\ Dr Pieter van \\ Niekerk (research \\ associate,US) \\ PO Box 503 \\ Great Brak River \\ 6525 \\ heaven@lantic.net
}

